\title{
Preaching and culture
}

\author{
T F J Dreyer \\ Reformed Theological College \\ University of Pretoria
}

\begin{abstract}
Preaching and culture

Before the new political dispensation in South Africa (1994), the Dutch Reformed Church in Africa (Nederduitsch Hervormde Kerk van Afrika) referred to the church as a "peoples church" (volkskerk). Owing to political changes the qualification "volkskerk" has created a certain degree of disturbance in the ranks of the church. The relationship between "church and culture" became a topical issue. Since 1994 the focus of the homiletical debate shifted to the question of the role of the church within a changing environment and again the answer to the question of "church and culture" was of utmost importance. Nowadays the reality of a multicultural society becomes a new challenge to the church. This article is an attempt to define the relation between culture and preaching from different hermeneutic perspectives, namely the cultural embedding of the biblical kerygma; the interwovenness of language and culture; and the necessity for contextuality in preaching.
\end{abstract}

\section{TOPICALITY OF THE STUDY}

The theme of "preaching and culture" from the perspective of missiology was previously a topical issue. In due course, reasonable consensus was reached that, for the sake of proclaiming the Gospel, the church would have to become "indigenous" to any culture whatsoever. In the church's missionary labour, a particular culture is not elevated to a prerequisite for faith, though the church has to interpret critically the message of the gospel in every context in which missionary action is taken. The question of the relationship between church and culture, and so also between preaching and culture, has therefore in a certain sense already been answered and it may seem superficially that the subject of this study has already been superseded. A brief bird's-eye view of the theological landscape makes one quickly realise, however, that this is still a burning issue and may perhaps be even more complex than the traditional question of the relationship between preaching and culture. This article is a reworked version of an article published in 1996. At that time, shortly after the 


\section{Preaching and culture}

commencement of the new political dispensation in South Africa, the question of the relationship between "church and culture" became a topical issue, on the one hand because of critical questions based on the church's involvement in the earlier dispensation, and on the other because there was uncertainty about the church's role in a situation of political change. Now, after nearly ten years, a new issue is emerging, namely that of diversity and multiculturality.

The homiletical debate in South Africa in the last decade of the previous century focused on the question of contextuality (Muller 1992:27-41; Van der Merwe 1989). Political changes in South Africa compelled the church to consider the role of preaching in a situation of change (Burger 1994:83-92; Pieterse \& Theron 1994:141-154). The political and social function of preaching is a focal point worldwide (Jossutis 1980; Arbuckle 1991). A new scenario is currently unfolding, namely that churches are increasingly being confronted with the phenomenon of multiculturality and diversity at a local level - "... we find that, first, diversity is a challenge to theology in its kerygmatic aspect: theology, in the service of the Church's proclamation, must recast those symbols" (Aidan Nichols 1999:11). In the context of Africa, churches are increasingly realising that they have not yet really succeeded in becoming indigenous to the culture of Africa. Kurewa (2000:9) is convinced that churches in Africa still function in "strange ways". They still sing mainly Western songs, with Western melodies, and consequently they do not sound like African people singing, but they do not sound like Westerners either. "As African Christians who now worship God through our knowledge of Him in Christ, we must worship God with the splendour of African cultures" (Kurewa 2000:9). He also claims that churches in Africa have not yet succeeded in finding an answer to the practice of traditional healers. Church members actually lead a double life, ${ }^{1}$ one as Christians and the other as people who are part of the Africa tradition (Kurewa 2000:11).

Contextuality has become a buzzword in theological debates. The contextuality of preaching is a wider concept which includes the political, social and cultural functions of preaching. The ideal for a contextual hermeneutics for the homiletic situation in the Republic of South Africa is formulated by Muller as follows:

It is a specific hermeneutics which wants to be of service to a public proclamation which does not isolate itself in the ghetto of an introverted cultist preaching, but is aimed at being heard and understood in the so-called "naked public square". As "public" hermeneutics it does indeed want to serve the ecclesiastic

\footnotetext{
${ }^{1}$ From personal experience over the past ten years in the training of ministers at Hammanskraal (Africa Institute for Missiology), I have come to the same conclusion. In discussing their sermons, students invariably show signs of their embarrassment at handling the existing practice of traditional healers and sangomas among congregation members.
} 
proclamation and articulate its identity by operating at the interface between exegesis and social analysis. In this hermeneutic perspective, the cultural realities are part of social analysis, but then in the context of the "naked public square".

(Muller 1992:27; my translation)

The question arises whether such an approach does not already imply the choice of a particular cultural view, namely that instead of being a church in a specific cultural group, the choice has apparently been made that the groupassociated cultural context of the church should give way to an intercultural context, which actually attempts to be a new culture. The culture of the "public square" now becomes the context for preaching, whereas in the past the "ghetto" of a particular cultural group was the context for preaching. When the "culture" of the "public square" is used as the context, the diversity of many cultural contexts is ignored.

The turbulence in the Dutch Reformed (Nederduitse Gereformeerde) Church concerning the possible union of the United Reformed (Verenigde Gereformeerde) Church and the Reformed Church in Africa, illustrates the importance of the cultural commitment of the church. P C Potgieter, the former dean of the theological faculty at the University of the Free State and former moderator of the Dutch Reformed (Nederduitse Gereformeerde) Church, stated in public that the Afrikaans language was so important that, if one were to ignore language, there would be a schism in the Dutch Reformed Church. The editor of the Sunday newspaper Rapport responded in an editorial, arguing straightforwardly that the church had a cultural task. The editor supported professor Potgieter's standpoint and substantiated it with the following argument:

Because in contrast to what certain churchmen wish to profess in a fashionable idiom nowadays, the church also has cultural roots and a cultural task. Through the centuries the church and the Christian faith were in the vanguard of civilisation, guardians of learning and literacy, and also of the arts and music. Whoever wishes to refer to language as merely a "cultural area", negates the church's important cultural roots.

(Rapport, 31 Maart 1996; my translation)

In the context of the Dutch Reformed (Nederduitsch Hervormde) Church of Africa, which is where this investigation was initiated, the theme of preaching 


\section{Preaching and culture}

and culture is a burning issue. In the other Dutch Reformed (Nederduitsch Hervormde) Church the notion of a "people's church" is a basic given and also the point of departure in thoughts about ecclesiological considerations (cf Botha 1989: Botha \& Pont 1993:1-19). The notion of a people's church was also crystallised in the well-known Article III of the Church Statute of the Reformed (Nederduitsch Hervormde) Church. In view of the compilation of a new Church Ordinance and the political changes in South Africa, the notion of a people's church has once again come under close scrutiny.

Van Eck (1995:827; my translation) puts it as follows: "Can an exclusive people's church be defended on Scriptural grounds? In my opinion, this is the question to which the Nederduitsch Hervormde Kerk will have to give serious attention in the future debate around the church ordinance." The discussions and resolutions during the General Church Meeting of 1995 put into words a little of the uncertainty that the challenges in the context of the "new" South Africa" have caused in the church. The meeting (Nederduitsch Hervormde Kerk of Afrika $1995=$ NHKA 1995) resolved among other things that Article III should be changed in a new church ordinance so that no racial references would come to the fore in wording the notion of a people's church. At the same time, the General Church Meeting confirmed that a people's church, though not the only configuration, was still the most obvious one for the church's existence, and that the Dutch Reformed (Nederduitsch Hervormde) Church of Africa was the people's church in the midst of the Afrikaner people (NHKA 1995:141-142). The General Church Meeting also expressed the opinion that the church had a cultural task and should still strive for a Christian education unique to its people (NHKA 1995:31.5-316). The Reformed Church accepted the responsibility for further extending the church's apostolic responsibility in the new context by planning a new ministry pattern in multicultural communities without letting the existing ministry patterns become lost in it (NHKA 1995:283). These resolutions testify on the one hand to the fact that the Reformed Church realises that the church's existence is intertwined with the cultural context in which the church lives, but on the other hand there is a sense of caution against elevating specific sociopolitical realities to an absolute level.

In the Church Ordinance approved in 1997, the matter is stated in the following words: "The church is a people's church with its own ecclesiastical culture, history, language and tradition, which was called to proclaim the Gospel of Jesus Christ to the Afrikaner people and simultaneously to all people" (NHKA 1997:67; my translation). The Church Ordinance also provides for the fact that in the new context of the "public square", the Church can establish different kinds of congregations with an adjusted pattern of ministry 
(NHKA 1997:70). With this provision, the Church implies that in future the Church will probably have to seek, especially in its apostolic labour, ministry structures which will be relevant in that context. In my opinion, the Church endeavours with these resolutions to provide for the interdependency of ecclesiastical ministry structures (including preaching and public worship) and the cultural context of homogeneous groups, as well as the diversity of the "public square".

The problem underlying the question posed about the relationship between church and culture, therefore also concerns the changes in politics and statecraft in South Africa. In the previous dispensation, cultural and group rights were the basis of community life, but these rights are no longer held in high esteem. A large part of the Afrikaner church community feels threatened by the new situation. Language and cultural rights are denigrated in various fields, for example especially in education. In this context it is a question to the church whether preaching and pastorate should be harnessed to guide and accompany its members. The aim of this investigation is therefore, more precisely, to attempt to determine what the relationship between culture and preaching is. First, an attempt will be made to outline briefly the contours of the problem. The relevance of the cultural context for preaching will be elucidated from a few homiletic perspectives, namely the Biblical message and culture; preaching as language-related word event and culture; contextuality and culture. To conclude, an attempt will be made to establish a few guidelines for preaching.

\section{CONTOURS OF THE PROBLEM}

Culture can be defined from different perspectives. Sociological, psychological, anthropological, political, communicative, philosophical and many more disciplines may be used, each from its own particular point of view, to shed light on the question of what is understood by the concept of culture. For the purpose of this study, the focus is not on only one particular facet of culture. Instead, the most comprehensive description of culture should be sought, in which all possible aspects of culture are incorporated. Only from such a holistic understanding of culture as a phenomenon can the question of possible interfaces between culture and preaching be asked.

Vroom (1995:5) holds the view that culture concerns traditional insights and learned attitudes, not only to receive insights and attitudes from the tradition to which people belong, but also to undertake in turn to pass them on deliberately to others. What is passed on is a pattern of meanings, for example what a table is and the purpose for which it is used. The explanatory Afrikaanse Woordeboek (1980:493) describes culture as the spiritual asset of a people in all possible areas: products, outcomes, creations, the handiwork 


\section{Preaching and culture}

of human activity and ingenuity; civilisation, development, refinement, cultivation, rebuilding. The larger explanatory Handwoordeboek van die Afrikaanse Taal (1985:625) defines culture as the entire spiritual property of a people in every field.

Culture is never the product of one person only. Even the lonely thinker has had teachers, preserves in his/her memory the meetings with fellow humans or reads the works others have written. Culture comes into being through co-operation. Culture is the sign that man is a creature who belongs to a community (Van Peursen 1955:9). Based on the original meanings of the Latin word cultus, cultura and the verb colo, Van Peursen (1955:15) deduces that as soon as people busy themselves carefully with something, culture comes into question. The word spans the broad field of human activities from agriculture to worshipping the gods, and from occupying a piece of land to caring for and adorning one's home and one's own body.

Seen thus, culture is not a given quantity, something that is objectively at hand, but instead is far more an event, a process encompassing man and his world, the inner and the outer (cf also Fahner 1990:26; Aidan Nichols 1999:10).

From these holistic perspectives, culture for the purpose of this study can be summarised as follows:

- It is the entire process of and interaction between inner values, thought and emotions, which crystallises in human conduct, acts and structures in all fields of life.

- It has a corporate dimension because culture originates in a particular community whose members share values and pass them on to the next generation. The corporate dimension is usually closely related to the concept of "people", which is a community that shares values.

- It is not a static given, but a dynamic process.

In view of this circumscribing of the concept of "culture", it is clear from the outset that preaching cannot ignore the reality of cultural processes. Starkloff (2000:410), following in the footsteps of Geertz, speaks of "religion as a cultural system", which is both a model for and a model of reality (cf Jonker 1973:25). In his consideration of the problem, Jonker (1973:69-94) indicates that the preacher has to learn what the specific questions, assumptions and institutions are to which preaching should be related. It is different, however, from laying down and adapting to a particular prevailing theology of the people, or going along with what the congregation says. Jonker gives a 
fascinating exposition of the way factors in society, culture, philosophy and politics have influenced preaching.

The way in which the Scriptures are interpreted, for example by allegory and typology, crystallised from specific philosophical trends. The change in forms of preaching, such as the transition from the simple homily amid the earliest home congregations and also in the catacombs during the times of persecution, gave way to the sermo, or cultural preaching, held in the basilica, as a result of Constantine's patronage of the church in 380 AD. Jonker came to the conclusion that, for this reason, the church would always be a people's church because its aim was to promote the gospel.

Chrysostom had already pointed out the dangers that the relationship between preaching and folk life held for the proclamation of the gospel, namely that it could make the State's form of ministers more servants of the State than servants of God (Jonker 1971: 88). When we acknowledge that the Word of God enters the situation (after all, we serve a living God who takes people seriously in their circumstances), we will have to admit at the same time that interpreting the truth in preaching also has to penetrate the contemporary situation and therefore also the culture. Oberholzer (1985:24) indicates, based on the ecclesiastical articles of faith that the church has a task to perform in the different fields of society by means of preaching and the pastorate. There is a grave danger that the essence of the gospels may be overwhelmed by influences emanating from the situation. Various research projects have already demonstrated that preachers' cultural and political ties have so greatly influenced preaching that justice is not done to the contents of the gospels. In a study by Celliers (1982) on an analytical model for sermons, the sermons of Allan Boesak, A P Treumicht and G von Rad were closely examined. Celliers came to the conclusion that although Von Rad's observation was determined by the commentaries, some of the South African ministers were unduly influenced by the situation, their cultural ties and politics.

Boesak and Treurnicht both interpret the Word selectively and attempt to claim God for their own cases. To both of them, observation takes place through the filter of their own interests (Celliers 1982:175). Treurnicht sacrifices ecclesia to the people, whereas Boesak proclaims an ecclesia in which Christ no longer seems to be present (Celliers 1982:192). In an empirical investigation by Bam (1991:124-135), he demonstrates how cultural and political considerations influenced preaching in the sermons of students at the University of Stellenbosch and the University of the Western Cape. He comes to the conclusion that it is not possible to disentangle the bond 


\section{Preaching and culture}

between preaching and context, but also points out the danger that preaching may be enslaved and humiliated to become a mere function of the context.

In a publication of the Reformed (Gereformeerde) Ecumenical Synod about the church and its social vocation (RES 1979), it is stated that member churches of the body hold widely divergent opinions on the aforesaid matter. These standpoints of member churches vary from a total distancing from social-cultural involvement at the one end of the spectrum, to a vision at the other end that the church together with other institutions is a co-partner in change (RES 1979:5).

In this wide spectrum of standpoints, an endeavour will have to be made to adopt a specific positioning, based on homiletic-hermeneutic considerations.

\section{THE BIBLICAL KERYGMA IN A CULTURAL CLOAK}

To shed light on the question of the relationship between preaching and culture, it is advisable for us to orient ourselves anew to the Bible, which is simultaneously the source of preaching and the guideline for all theological consideration (cf Jonker 1973:57). The acknowledgement that the Scriptures are bound by culture and time paves the way for the sovereign tenor of the Word of God in pre-modem and post-modern communities. Fahner (s a:24 ff) proceeds from the standpoint that the Biblical message is enveloped in a timebound cultural context. This may lead to parts in which a specific culture is clearly present, being deemed less important for preaching. He mentions that another possible approach may be to distinguish between form and content. The cultural packaging could therefore be discarded and the message retained. Fahner (s a:25) states that this approach can be ascribed in particular to the influences of the Greek philosophers. Such a rigid distinction cannot be made as if the message would eventually exist independently. The Biblical message is an event which invites reaction and interaction.

For this reason, preaching does not entail divesting the Biblical message of its cultural cloak; preaching is the challenge to allow the dynamic contents of the event of transculturation to grow in a new cultural seedbed.

Malina (1993:xi) states: “... all language derives its meanings from the societal system and cultural context in which the language communication originally takes place." Malina calls his approach to understanding the New Testament an "incarnative" approach. His method envisages enabling readers to reconcile themselves to the fundamental values and perspectives of the Mediterranean world of antiquity, since these values and perspectives are the foundation of the whole New Testament. 
These few thoughts amply illustrate that the Biblical kerygma is shrouded in a cultural cloak and that this "cloak" cannot be shaken off without further ado in preaching, and that only a pure message can be conveyed to the congregation. Preaching the Biblical kerygma will always again be shrouded in the cultural cloak of an own context. This is the secret and the challenge, but at the same time also the risk of preaching. The preacher will have to be thoroughly aware of the dangers and risks. Venter (1983:110-122) points out the hermeneutical disturbances that may occur if it is accepted that there is a linear analogy between the socio-political systems of the Old Testament and those of today's world. Seen historically, a modern system is being equated with a classical structure; and seen philosophically, the antique system becomes prescriptive for the present system.

Seen hermeneutically, this means that the authority of the Scriptures operates in the social structures that the Scriptures describe (Venter 1983:112). Consequently, a hermeneutic method will have to be sought in preaching, a method which avoids the danger of a linear analogy but at the same time does justice to the cultural bond of both the text and the sermon. Two such possibilities have been indicated above, namely that either via the process of transculturation or through an "incarnative" approach, the dynamic contents of one context can be transferred to a new context. This transfer takes place through a merging of the horizons in which the events in the Word are fulfilled. In this process the own cultural context in preaching will have to become fully crystallised.

\section{PREACHING AS LANGUAGE-RELATED EVENT}

Wethmar (1977:164) indicates that Ebeling, in his attempt to account for the sermons of God for our time, as a first step analysed the phenomenon of words and language. Ebeling (1969:409) emphasises that time and context have a constitutive meaning for the reality of language. A word occurs as a time-associated event. Therefore to the word belongs the situation from which the word arose as well as the situation it goes into and changes (Pieterse 1979:42). To understand the essence of a word, we should not ask about the word's content, but about its effect, what established the word and what will happen through the word. A word event takes place in preaching through a melting of the horizons of understanding (Pieterse 1979:113).

As a language-related event, preaching will therefore have to take careful account of the time-relatedness and situation-relatedness of language. In outlining a hermeneutic-communicative theory of sermons, Vos (1995:164vv) moves in the direction of a symbolic interactional model of communication. According to this model, the communication process takes 


\section{Preaching and culture}

place in a specific life-world in which there are certain systems, such as marriage, the family, labour, sport and culture (Vos 1995:166). When preaching is therefore defined in terms of communication theories, the effect of culture, groups and subsystems should not be underestimated.

The importance of culture to preaching is underlined further when noting the interwovenness of language and culture in the communication process. Haarmann (1980) thinks that the cultural embedding of language is the cornerstone of a comprehensive theory of communication. Language as a system of signs and symbols is a cultural phenomenon in which the collective experience of participating speakers is reflected and from which the community's patterns and structures of social values are crystallised (Haarman 1990:viii). "It is the cultural dimension of sign systems, whether they are language-related or not, which makes human communication unique" (Haarman 1990:ix). In his attempt to redefine identity, Fitzgerald (1993:7) also points out the interdependence of culture, identity and communication. In his discussion of post-liberal theology and the cultural-linguistic approach of Lindbeck, Buitendag (2002:13-17) indicates that religion functions in a cultural framework which shapes the lives and judgement of those involved. Language is an integral part of this framework. "In particular, the fact that community or group form such an integral part of Postliberal theology as opposed to an Evangelical individualism, is extremely important. But then community should also be understood culturally and it also gives room for equivocality" (Buitendag 2002:16; my translation).

The matter can be made a greater problem if, in addition to the two horizons of the text and the interpreter, a third horizon is also distinguished, namely that of the respondents. Hesselgrave (1985:443-454) remains engaged in the question of how cultures can be integrated into the communication process, especially when the culture of the interpreter and respondent differ from each other. He indicates that this third horizon poses tremendous challenges to preaching, especially in a Third World situation. When this third horizon is not interpreted and contextualised correctly, the message becomes distorted. When applied to the situation of the Afrikaans churches, it calls into question whether, in the plural society we live in, there is not already a gap between the horizon of the interpreter and the respondent.

If culture and context as communicative events play such a large role as shown above, then the preacher will also have to take this third horizon seriously. Preaching as a language-related event in the communication process accentuates the fact that preaching can never be alien to culture.

\section{PREACHING AND CONTEXTUALITY}

As shown above, the homiletic debate in South Africa has focused mainly on the contextuality of preaching in a situation of transition (cf Pieterse 1995:50- 
56; Muller 1992:27-41; Burger 1994:83-93; Pieterse \& Theron 1994:201-217; Vorster 1994:14-20; Bam 1991:124-135; Van Niekerk 1993:67-73; Odendaal 1990:4562).

In particular, it was Muller (1992:27) who tried to develop the importance of contextual hermeneutics for the homiletic situation in South Africa. The hermeneutics should function at the interface between exegesis and social analysis. His reason for pleading for the establishment of such a "public" hermeneutics was built on the ideas of, for example, Josuttis (1980:41 $\mathrm{ff})$, Van Seters (1991:267ff) and others, emphasising that the horizons of understanding the text and understanding a social reality have to be transposed over each other. This understanding of social reality encompasses society with its wealth of culture and pluriform ways of expressing life (Muller 1992:28).

He also contends that the church may think it can purify the Biblical message from impurities with a so-called emphasis on the spiritual and the inner life at the cost of social relevance, but that such an attitude essentially makes preaching powerless. According to Long (1989:84) the task of preaching is precisely to articulate the identity of the community of the faithful within the reality in which its members live. To this end, an accountable social hermeneutics, built on a scientific social analysis, is essential (Muller 1992:30). This analysis has to be done in the space of public life, in the market square.

Pieterse and Theron (1994:152) hold the opinion that it is necessary to take the current context into account in our theologising. A clear broadening has taken place in the praxis concept. Heitink (2000:19) emphasises this broadening of the praxis concept by distinguishing between praxis 1 (the medial acts of the church) and praxis 2 (the context in which the act takes place). Context also means the context of society, because it is the context in which the church exists and does its work. Celliers (2002:149) is convinced that it is not a question whether contextualisation should take place, but solely how? He defines contextualisation as an attunement with the congregation, since the Word of God can never be disentangled from the people of God (2002:144). The congregation introduces the wider contexts in which preaching plays its role (socio-economic, political, ecological, ethical, cultural) in the game of the sermon-making process.

The demand for contextualisation becomes a greater problem as a result of the phenomenon of multiculturality and diversity in certain communities. The church no longer serves a homogeneous cultural group, particularly in urban areas, as congregations have people of different ethnic, language and cultural backgrounds who are in varying stages of being assimilated into a larger community (Starklof 200:421). Nieman and Rogers 


\section{Preaching and culture}

(2000:vii) began an investigation into the possibility of cross-cultural strategies for preaching, aimed at helping ministers in the American ecclesiastical community to bridge the cultural diversity in one congregation.

In addition to the political and social changes in South Africa, the postmodern paradigm is also radically changing our society. Sweet (1999:17) compares the impact of postmodern thought with a tsunami wave which is going to engulf us. In addition, the Internet, the "global village" and visual communication have an incalculable influence on the context in which the church has to proclaim the gospel. If the church does not take account of this totally new context, which has an influence across different cultures, this context will engulf the church like a tsunami. But if the church could read and interpret the times correctly, this would offer the church unprecedented possibilities (cf Taylor 2000:3-8; Nishioka 2000:39-44; Mitchell 1997:262-272).

The approach of a contextual hermeneutics can correspond with an underlying theory of sermons, which wants preaching to have a say in the lifereality of the community of the faithful. In terms of this theory, preaching would have to be concretised in the social reality, which takes account not only of culture but the total praxis. In principal the theory is sound at heart and it frees preaching and faith from abstractness. The question is, however, what this context comprises and how is it identified?

\section{CONCLUSION}

It is clear from the few homiletic perspectives exploited in the investigation that preaching and culture are closely interwoven. Preaching can never be culture-free. The Biblical kerygma comes to us enveloped in the cultural cloak of the Mediterranean world of that time. The Biblical message cannot be conveyed except through the process of interpreting it in a new cultural context. Preaching as a language-related event binds preaching inextricably with culture as the basis for the common understanding of language symbols. A contextual hermeneutics takes as its point of departure a social analysis which operates with a broadened concept of praxis and also implies the cultural facet.

The focus has obviously shifted from cultural preaching to the contextuality of preaching, which includes culture. That the cultural given is a sine qua non for preaching also came clearly to the fore. The church does not have a cultural task and does not elevate one culture to the absolute, but culture is an integral part of the context in which the gospel has to gain stature.

The danger associated with a contextual hermeneutics is that it may degenerate into political preaching under a new name. Aidan Nichols (1999:12) rightly points out the importance of the interaction between preaching and culture, but at the same time indicates the danger "... when the 
functioning of culture goes awry ... and the temptation thus arises for a theology which would take its cue from such a culture to conceive of its task in purely horizontal categories". Starkloff (2000:422-425) therefore warns that religion and ideology are interwoven cultural systems which have many symbols in common. The church can easily be seduced into enjoying the benefits of belonging to a specific cultural system, or committing itself to a certain political dispensation, but when this alliance manifests the church relinquishes its vocation as a prophetic community.

When applied to the Dutch Reformed (Nederduitsch Hervormde) Church, the concept of "people's church" could still be maintained, as long as it means that the proclamation in the Reformed Church is directed at a particular people or cultural community, and therefore wants to give shape to the message of the gospel in that cultural community. Preaching cannot but put into the words of sermons the experiences of the members in a situation of change and uncertainty. Preaching also has the purpose of helping people in a new cultural context to articulate their identity as a community of the faithful. The church and therefore preaching do not have a direct cultural task, but because proclaiming the gospel is aimed at people in a particular context, the effect of preaching will call on people of the faith to be critical of their own culture too. Consequently, preaching has a cultural effect in an indirect way.

If the Reformed Church takes seriously the context in which the gospel is proclaimed, every preacher will have to consider actively how best to accommodate diversity in the congregational set-up. Whether we want to accept it or not, the congregations of the Church have for some time not been a homogeneous group of like-minded thinkers. Janse van Rensburg (2003:8) judges that in preaching today we deal with three types of people: the postmodern people; the people who are consciously or unconsciously influenced by postmodern ideas; and the people who reject postmodernism. Whatever the case may be, the modern context to a large extent pervades the postmodern climate of life and this increasingly influences those who hear preaching. Preachers will have to take this into account, because it requires a different style, or rhetoric, in our preaching.

The paradigm shift from modernism to postmodernism had a definite impact on preaching. The move away from a kerygmatic approach towards a hermeneutic understanding of communication inevitably caused a move away from a deductive approach to an inductive way of preaching.

(Janse van Rensburg 2001:340) 


\section{Preaching and culture}

Lose (2003:172-177) states aptly that objectivity is an illusion. I come to the text with questions and presuppositions. The text can only speak to me if I also speak to the text. In this way a critical dialogue ensues between the text and me. We do not go to the text as passive, neutral interpreters, but as living confessing Christians full of questions, hope, doubt and expectation. Your pastoral experience is the first frame of reference for your questions to the text and your theological tradition is the second role player. Seen like this, an intense pastoral relationship between preachers and members of the congregation is the first step in the direction of a contextual hermeneutics. Sermon working groups, also involving members of the congregation, can help the preacher to put the context of the congregation into words in a better way.

The greatest challenge confronting the Reformed Church, however, is not solely to proclaim the gospel in the context of Afrikaner communities. If the Church really wants to understand the essence of the church from the missio Dei, the Church will have to penetrate the context of the "public square", which will necessarily demand alternative structures for services. Time will tell whether the Church seriously meant the decision that "other kinds" of communities could be formed to fulfil this need.

\section{Works consulted}

Aidan N, O P 1999. Christendom awake: On re-energising the church in culture. Edinburgh: T\&T Clark.

Arbuckle, G A 1991. Grieving for change. London: Geoffrey Chapman.

Bam, G 1991. Prediking en konteks: 'n ondersoek na die neerslag van konteks in die proefpreke aan die Universiteit van Stellenbosch en die Universiteit van WesKaapland 1987. NGTT 32, 124-135.

Botha, S J (red) 1989. Belydende volkskerk. Pretoria: Kital.

Botha, S J \& Pont, A D 1993. Inleiding tot die nuwe Kerkorde, 'n Konsep Kerkorde en Ordinansies, 1-19. Nederduitsch Hervormde Kerk van Afrika.

Buitendag, J 2002. Postliberale teologie as teologiese raamwerk vir die kerk se korporatiewe identiteit. HTS 58, 1-25.

Burger, C W 1994. Die agogiese moment in die prediking in 'n situasie van verandering. Praktiese Teologie in Suid-Afrika 9, 83-92.

Celliers, J H 1982. Soos woorde van God: Ontwerp van 'n preekanalitiese model. DTh-proefskrif, Universiteit van Stellenbosch.

Celliers, J 2002. Die geheim van die prediking: In-stemming kom met die gemeente. HTS 58, 143-156.

Ebeling, G 1969. Wort und Glaube, II. Tübingen: Mohr.

Fahner, C \& Van Laar, W 1990. Evangelie als cultuur. Kampen: Kok.

Fitzgerald, T K 1993. Metaphors of identity. Albany, NY: State University of New York Press.

Haarmann, H 1990. Language in its cultural embedding. New York: Mouton de Gruyter. 
Heitink, G 2000. Practische Theologie, 2de druk. Kampen: Kok.

Hesselgrave, D J 1985. The three horizons: Culture, integration and communication. JETS 28, 443-454.

Janse van Rensburg, J 2003. Narrative preaching: Theory and praxis of a new way of preaching. Acta Theologica, Suppl 4.

Jonker, H 1973. En toch preken. Nijkerk: Callenbach.

Jossutis, M 1980. Praxis des Evangeliums zwischen Politik und Religion. München: Kaiser.

Kurewa, J W Z 2000. Preaching and cultural identity: Proclaiming the Gospel in Africa. Nashville, TN: Abingdon Press.

Long, D J 1989. The witness of preaching. Westminster, KY: John Knox Press.

Lose, D J 2003. Confessing Jesus Christ: Preaching in a postmodern world. Grand Rapids, MI: Eerdmans.

Malina, B J 1993. Windows on the world of Jesus: Time travel to ancient Judea. Louisville, KY: John Knox.

Mitchell, J 1997. Preaching in an audio-visual culture. Anvil 14, 262-272.

Muller, B A 1992. Hermeneutiek op die intervlak tussen eksegese en sosiale analise. Praktiese Teologie in Suid-Afrika 7, 27-41.

Nederduitsch Hervormde Kerk van Afrika. Algemene Kerkvergadering 1995.

Notule van die Algemene Kerkvergadering 1995. Argief van die Nederduitsch Hervormde Kerk, Pretoria.

Nederduitsch Hervormde Kerk van Afrika. Kerkorde Algemene Kerkvergadering 1997. Argief van die Nededuitsch Hervormde Kerk, Pretoria.

Nieman, J R \& Rogers, T G 2001. Preaching to every pew: Cross-cultural strategies. Minneapolis, MN: Fortress.

Nishioka, R 2000. Preaching and youth in a media culture. Journal for Preachers 42, 39-44.

Oberholzer, J P 1985. Die taak van die kerk teenoor die owerheid. HTS 42, 14-28.

Odendaal, D H 1990. Benadering van en prediking uit die Ou Testament in die Afrika konteks. Theologia Viatorum 17, 45-62.

Pieterse, H J C 1979. Skrifverstaan en prediking. Pretoria: NG Kerkboekhandel.

Pieterse, H J C \& Theron, J P J 1994. Die begeleiding van Afrikaanssprekende kerk lidmate deur die prediking in die staatkundige oorgangsproses. Praktiese Teologie in Suid-Afrika 9, 141-154.

Pieterse, H J C 1995. Eksistensiële prediking in die oorgangstyd. NGTT 36, 50-56.

Reformed Ecumenical Synod 1979. The church and its social calling. Grand Rapids, MI.

Starkloff, C F 2000. The church as covenant, culture, and communion. Theological Studies 61, 409-431.

Sweet, L 1999. Soul tsunami: Sink or swim in new millennium culture. Grand Rapids: Zondervan.

Taylor, B B 2000. Preaching repentance at the start of a New Millennium. Journal for Preachers 23, 3-8. 


\section{Preaching and culture}

Van der Merwe, C F 1989. Context and theology in Southern Africa: A shift in theological paradigm. DTh dissertation, University of Western Cape.

Van Eck, E 1995. J H J A Greyvenstein en A S Geyser oor die volkskerkgedagte. HTS 51, 825-850.

Van Niekerk, A 1993. Politieke prediking, die Ou Testament en die NG Kerk. NGTT 34, 67-73.

Van Peursen, C A 1955. Cultuur en Christelijk geloof. Kampen: Kok.

Van Seters, A 1991. The problematic of preaching in the third millennium. Interp 45, 267-280.

Venter, P M 1983. Sosio-politieke relativering van die Bybel. HTS 39, 110-122.

Verklarende Afrikaanse Woordeboek 1980. s v kultuur.

Verklarende Handwoordeboek van die Afrikaanse Taal 1985. s v kultuur.

Vorster, J M 1994. Prediking in 'n Afrikakonteks. PTSA 9, 14-19.

Vos, C J A 1995. Die blye tyding. Pretoria: RGN.

Vroom, H M 1995. Evangelie en cultuur: Hun onderlinge verhouding. GTT 95(1), 311.

Wethmar, C 1977. Dogma en verstaanshorison. Amsterdam: Rodopu. 